DOI 10.14746/ssp.2016.1.11

Сергей ФЕдорченко, Сергей Мякотин

Московский государственный областной университет, Москва

\title{
Эхо партийного менеджмента: доверие московской молодёжи к Государственной Думе Российской Федерации
}

\begin{abstract}
Аннотация: Научная статья основана на результатах социологического исследования молодежи города Москвы по итогам партийного менеджмента и партийной реформы в современной России. Анализ показал, что наблюдается некоторая дуальность позиций московской молодежи по отношению к Государственной Думе Российской Федерации. Исследователи делают вывод, что молодежь из частного сектора, в большей степени интересующаяся политикой в отличие от работников бюджетной сферы, поддерживает политический курс действующего президента и готова голосовать за партию «Единая Россия», хотя и критически оценивает сам институт парламентаризма. Тогда как молодежь из бюджетного сектора меньше интересуется политикой и одобряет в большей или меньшей степени работу Государственной Думы России, считая, что она представляет интересы простого населения.
\end{abstract}

Ключевые слова: партийный менеджмент, Государственная Дума Российской Федерации, российские партии, парламент, молодежь Москвы, демократия

Современными зарубежными и отечественными политолои их равнодушное отношение к институтам политических партий и парламентаризма. И это, несмотря на то, что в 2012 году в России прошла партийная реформа, когда были внесены корректировки в федеральный закон «О политических партиях». Либерализация партийного менеджмента означала снижение минимальной численности партий с 40 тысяч до 500 человек. Действительно, после этой реформы количество политический партий в России увеличилось. Но запросы россиян новый партийный менеджмент так и не смог удовлетворить (Абрамов, Федорченко, 2014).

Разочарование россиян в политических партиях и абсентеизм имеет глубокие причины. На риски подобного рода обращают и за- 
рубежные исследователи, считая, что современные партии стали электоральными машинами, использующими маркетинговые манипуляции лишь с целью удержания веса в парламенте. На деле же связь партий с обществом становится все более формальной - партии меньше стали отражать интересы граждан. Например, Норберто Боббио в обосновании «демократического элитизма» утверждал, что специфическим маркером сегодняшней демократической системы является конкуренция нескольких элит (Bobbio, 1984). Иными словами, элиты лишь умело скрываются под фальшивым, мнимым соперничеством политических партий. И это мировая тенденция, а не только российская.

Апатия к партиям самым негативным образом отразилась также и на отношение россиян к парламенту. Доказательством этого послужили результаты проведенного нами социологического обследования.

Основной целью настоящего социологического опроса было изучение уровня доверия российской молодежи к парламенту, как к институту власти. Для решения поставленной цели были обозначены следующие задачи:

- исследование уровня политизированности молодежи;

- выявление уровня поддержки парламентских и непарламентских партий среди молодежи;

- изучение порога доверия молодежи к представителям власти;

- обнаружение мотивирующих аспектов при выборе кандидата на голосовании по партийным спискам;

- анализ оценки удовлетворенности респондентов работой действующей Государственной Думы Российской Федерации;

- определение количества молодежи, принадлежащей к какой-либо партии;

- исследование уровня доверия молодежи к парламентским партиям;

- подтверждение или опровержение гипотезы о том, что представители молодежи бюджетной сферы больше доверяют выстроенной модели власти, чем представители молодежи из частной, небюджетной сферы.

Организаторы сочиологического проекта: Федорченко Сергей Николаевич, доцент, к. полит. н. (куратор проекта), Мякотин Сергей Алексеевич (основной координатор проекта).

Аналитическая группа: Бондарева Екатерина (ведущий коор- 
динатор группь), другие участники: Кудрина Анна, Афанасьева Анастасия, Петров Андрей, Ванифатов Алексей, Алдошкин Владимир, Анашин Никита, Васильева Кристина, Вострикова Маргарита, Гринь Павел, Грязнова Дарья, Гужев Дмитрий, Зиберев Андрей, Кабанов Вадим, Корнеева Софья, Кузнечзова Юлия, Липина Ольга, Михайлик Александра, Сидорков Алексей, Смирнова Анна, Тазова Мария, Терентьева Анастасия, Юрецкая Ксения (студенты-бакалавры Московского государственного областного университета по направлению подготовки «Политология»).

Опрос проводился методом личного интервью. В качестве генеральной совокупности было выбрано все взрослое население города Москва от 18 до 34 лет, постоянно проживающие на исследуемой территории.

Применялась связная квота по полу и возрасту. Исследованием были охвачены представители основных социально-профессиональных групп.

Всего в опросе приняли участие 999 респондентов. (Линейное распределение ответов на вопросы анкеты «Доверие молодежи к парламенту, как к институту власти»). Для получения объективной картины партийного менеджмента в России, наш анализ будет построен следующим образом: после эмпирических данных в таблицах станут объясняться полученные по конкретному вопросу ответы, затем мы сравним данные нашего опроса с результатами других сочиологчческих исследований.

Таблица 1

Уровень интереса молодёжи к политике

\begin{tabular}{||l|c|}
\hline \multicolumn{1}{|c|}{ Интересуетесь ли вы политикой? } & В целом по выборке \\
\hline Безусловно, интересуюсь & $35 \%$ \\
\hline Скорее интересуюсь & $29 \%$ \\
\hline Скорее не интересуюсь & $24 \%$ \\
\hline Совершенно не интересуюсь & $8 \%$ \\
\hline Затрудняюсь ответить & $4 \%$ \\
\hline
\end{tabular}

Ответы на первый вопрос нашего исследования свидетельствуют, что в совокупности более половины (64\%) молодежи Москвы в большей или меньшей степени интересуются политикой (причем безусловный интерес выражают 35\% респондентов). Это может 
быть обусловлено, во-первых, спецификой генеральной совокупности: Москва как столица государства является политическим центром России, и ее жители наиболее активно участвуют в политической жизни страны, выражают свои политические предпочтения (таблица 1). Такие результаты могут объясняться и тем, что молодежь является наиболее мобильной, деятельной и активной социально-демографической группой. Во-вторых, опрос проводился в ноябре 2014 года в период введения новых санкций против России в связи с геополитической ситуацией вокруг Украины. То есть высокий интерес может быть обусловлен как и за счет обострения отношений с новой украинской политической элитой, так и за счет увеличивающегося влияния последствий принимаемых политических решений на повседневную жизнь рядового гражданина. Кроме того, сами технологии российского партийного менеджмента наиболее активно апробируются именно в Москве (Schläger, Christ, 2014).

Таблица 2

Гипотетические выборы в Государственную Думу России по партийным спискам

\begin{tabular}{||c|c|}
\hline \multicolumn{1}{|c|}{$\begin{array}{c}\text { Какой партии Вы бы отдали предпочтение на } \\
\text { гипотетических выборах в Госдуму? }\end{array}$} & В целом по выборке \\
\hline Единая Россия & $37 \%$ \\
\hline ЛДПР & $7 \%$ \\
\hline КПРФ & $9 \%$ \\
\hline Справедливая Россия & $6 \%$ \\
\hline Непарламентская партия & $5 \%$ \\
\hline Не пойду на выборы & $21 \%$ \\
\hline Затрудняюсь ответить & $15 \%$ \\
\hline
\end{tabular}

Если бы выборы произошли в ближайшее время (на период проводимого исследования), наибольшее количество голосов набрала бы господствующая партия - Единая Россия (37\% без учета явки). При этом всего 5\% голосов было бы отдано за непарламентские партии, что может свидетельствовать о нежелании менять состав ныне действующий Госдумы, а также о недостаточной информированности о новых партиях, в связи с их регистрацией только в 2012 году, когда были внесены изменения в Федеральный закон „О политических партиях". 
У значительной доли респондентов (15\%) ответ на данный вопрос вызвал затруднения, что может говорить о слабой политической идентичности. Каждый 5 респондент (21\%) не стал бы принимать участие в выборах (таблица 2). Таким образом, довольно высока доля абсентеистов, но при этом, больше половины (64\%) молодежи Москвы пойдут на выборы с точным пониманием, кому отдать свой голос.

Всероссийский центр изучения общественного мнения (далее - ВЦИОМ) проводит еженедельные измерения рейтинга электоральной поддержки политических партий среди населения всей России. Сравнение результатов исследования за 15 февраля 2015 года с результатами нашего опроса позволит выявить отличительные черты в электоральном поведении московской молодежи (Электоральный).

Сравнительный анализ социологических опросов показал, что расхождение в рейтингах парламентских партий небольшое: разница популярности их среди молодежи в сравнении с популярностью среди россиян в целом не превышает $2 \%$, всего на $3 \%$ больше популярность непарламентских партий. Намного меньше, а именно на $20 \%$, популярность среди московской молодежи партии Единая Россия по сравнению с показателем всей страны (ВЦИОМ от 15 Февраля 2015 - 59\%). Выше оказалась среди молодежи Москвы доля тех, кто затрудняется ответить - 15\% по сравнению с 9,8\% (ВЦИОМ от 15 Февраля 2015 - 59\%) среди россиян в целом, что, практически, вдвое больше. Также среди молодежи выше доля тех, что не пошел бы на выборы - 21\% против 12,8\% (ВЦИОМ от 15 Февраля 2015 - 59\%). Подобные негативные результаты должны явиться тревожным сигналом не только для Единой России и правящей политической элиты, но и для всей партийной и парламентской системы: молодежь, как будущие страны, как ее движущая сила, показывает тенденцию к абсентеизму и низкой политической идентичности.

Технологии партийного менеджмента (партийные стартапы; рекрутинг партийных активистов и управление партийными функционерами, подразумевающие карьерные лифты для молодежи; вербовка новых сторонников партии; политический фандрайзинг и т.п.) не были ориентированы на формирование демократического имиджа парламента и партийной системы в России (Штоль, Федорченко, 2013). И это, в свою очередь, оттолкнуло молодёжь от подобных политических институтов. 
О Госдуме и ее работе

\begin{tabular}{||c|c|}
\hline $\begin{array}{c}\text { Оцените насколько вероятно, по вашему мнению, } \\
\text { что поддержанная вами партия, выполнит } \\
\text { предвыборные обязательства }\end{array}$ & В целом по выборке \\
\hline Безусловно, выполнит & $8 \%$ \\
\hline Скорее выполнит & $24 \%$ \\
\hline Выполнит только часть & $23 \%$ \\
\hline Скорее не выполнит & $20 \%$ \\
\hline Точно не выполнит & $7 \%$ \\
\hline Затруднились ответить & $18 \%$ \\
\hline
\end{tabular}

Заслуживает интереса тот факт, что, по мнению 32\% респондентов (лидирующий показатель), политическая партия, за которую они отдадут голос, выполнит свои предвыборные обязательства (8\% - безусловно, выполнит, 24\% - скорее выполнит). 23\% полагают, что партия выполнит только часть обязательств. $27 \%$ респондентов считают, что предвыборные обязательства выполнены не будут (при этом только 7\% из них, утверждают это с полной уверенностью). Следовательно, мнения распределились примерно поровну, но лидирует точка зрения, согласно которой партии в той или иной степени выполнят свои предвыборные обязательства (в совокупности 55\%). К слову, затруднились ответить $18 \%$ респондентов (таблица 3 ). Возможно, это связано с низким интересом к политике и, в частности, к выборам и предвыборным обещаниям политических партий. (Что на деле показывает уверенность населения в низком общественном контроле деятельности партий и неверие в выполнение партиями предвыборных программных заявлений).

Таблица 4

\section{Мотивации голосования за ту или иную партию}

\begin{tabular}{||l|c|}
\hline \multicolumn{1}{|c|}{$\begin{array}{c}\text { Что, на Ваш взгляд, является наиболее важным при } \\
\text { голосовании за партию? }\end{array}$} & $\begin{array}{c}\text { В целом } \\
\text { по выборке }\end{array}$ \\
\hline Программа партии & $29 \%$ \\
\hline Лидер партии & $21 \%$ \\
\hline Победа на предыдущих выборах & $0 \%$ \\
\hline Принятие решений, поддерживаемые большинством общества & $4 \%$ \\
\hline Поддержка партии президентом & $20 \%$ \\
\hline Степень оппозиционности к партии власти & $7 \%$ \\
\hline Выполнение предвыборных обязательств & $19 \%$ \\
\hline Другое & $0 \%$ \\
\hline
\end{tabular}


Согласно данным нашего исследования, большое количество респондентов (29\%) ориентируются на программу партии при голосовании. Сравнимое количество молодежи ориентируются на лидера партии (21\%) и на поддержку партии президентом (20\%). Что может говорить о желании «персонифицировать» политику, о восприятие процесса выборов в Государственную Думу не как борьбу идей, а как борьбу личностей. Одновременно высокая доля тех, кто возлагает свой выбор на действующего президента, может говорить о понимании сильной зависимости от него Государственной Думы (таблица 4). Совсем незначительное влияние на выбор партии оказывают, во-первых, степень ее оппозиционности (7\%), и, во-вторых, принятие решений, поддерживаемых большинством (4\%). Практически каждый пятый (19\%) респондент при голосовании учитывает выполнение партией предвыборных обязательств. На основании этих данных можно предположить, что наиболее важными мотивами выбора той или иной политической партии являются, во-первых, конкретные предложения партии, а во-вторых, конкретный человек, который эти предложения претворять в жизнь. Активная ассоциация партии с имиджем её политиков закономерна в условиях маркетизация современной политической сферы, когда образы политических лидеров становятся товарами, оттесняя на второй план партийные программы (Henneberg, Scammell, O’Shaughnessy, 2009).

Почти аналогичный опрос на тему мотивации голосования за ту или иную партию провел Левада-центр в ноябре 2011 года с возможностью дать несколько ответов (Мотивации). Согласно его результатам, лидирующими мотивациями являются - симпатия к лидеру (лидерам) партии (34\%) и разделение программ и лозунгов (32\%). Подобные показатели соответствуют данным нашего опроса, по результатам которого выше указанные мотивации также явились лидирующими (29\% и $21 \%$ соответственно). Также к нацеленным на лидера можно отнести и тех респондентов, кто ориентируется на поддержку партии Единая Россия президентом (20\%). Получается, что мотивы голосования молодежи Москвы не сильно отличается от мотивов россиян в целом.

Особенно любопытен в этом отношении опрос, проведенный ФОМ в декабре 2013 года на тему «О Госдуме и ее работе», где был задан следующий вопрос: «Одни считают, что Государственная Дума должна поддерживать президента во всех его начинаниях 
$(O$ Госдуме). Другие полагают, что Дума должна принимать решения независимо от мнения президента. С какой из этих двух точек зрения вы согласны?». Мнения разделились примерно поровну: за то, чтобы Государственная Дума поддерживала президента во всех его начинаниях, высказался $41 \%$ респондентов; а за то, чтобы Дума принимала решения независимо от мнения президента, выступили $43 \%$ опрошенных. Если сравнивать результаты нашего исследования с опросом ФОМ, то можно заметить некоторое сходство. Кроме того, часть молодежи также выступает за сильную власть президента, за его сильное влияние на Государственную Думу (т.к. высока доля тех, кто возлагает свой выбор партии на президента (20\%), а также высока доля поддержки партии власти (37\%) без учета явки, с учетом - 55\%). Данный феномен во многих странах связан с активной деятельностью политических менеджеров и консультантов, работающих на властную элиту (Дмитриев, Журавлёва, Федорченко, 2011, с. 155-161).

\section{Таблица 5. Оценка респондентами уровня работы действующей} Государственной Думы России

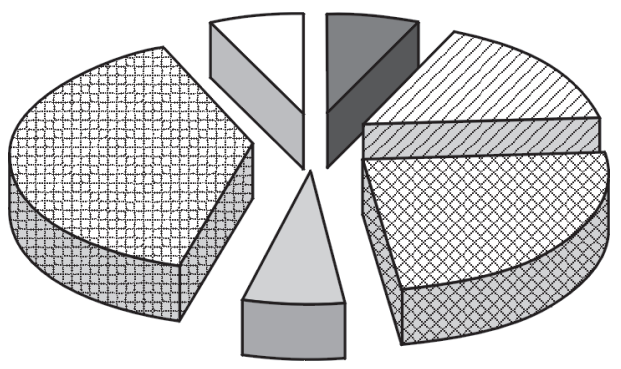

$\square$ Отлично (7\%)

$\square$ Хорошо (17\%)

Средне $(\mathbf{2 4 \%})$

$\square$ Удовлетворительно (6\%)

图 Неудовлетворительно (39\%) Затруднились ответить (7\%)

По нашему опросу, 24\% респондентов довольны работой Госдумы (при этом 7\% дали оценку «отлично», а 17\% - оценку «хорошо»). Почти половина респондентов (45\%) низко оценивает работу Госдумы (39\% ответили неудовлетворительно, 6\% - удовлетворительно). При этом оценку «средне» дали 24\% (таблица 5). Таким образом, наибольшее количество процентов приходится на оценки «средне» и «неудовлетворительно» (лидирующий показатель).

Согласно опросу ВЦИОМ (Одобрение деятельности), деятельность Государственный Думы РФ одобряют 45\% населения, что меньше на $3 \%$ (не больше статистической погрешности) среди мо- 
лодежи Москвы - 48\% (оценки: «отлично» - 7\%, «хорошо» - 17\%, «средне» - 24\%). Тогда как 30\% населения не одобряют детальность Думы, что меньше на 15\% по сравнению с московской молодежью - 45\% (оценки: «удовлетворительно» - 6\%, «неудовлетворительно» - 39\%). Учитывая дуальность предложенной ВЦИОМ оценки работы Госдумы (вследствие чего затрудняющихся ответить респондентов оказалось в 3,5 раза больше) можно предположить, что мнение молодежи Москвы не сильно отличается от мнения россиян в целом.

Таблица 6. Уровень активности политических партий, по мнению респондентов, в течение последних трех месяцев ${ }^{1}$
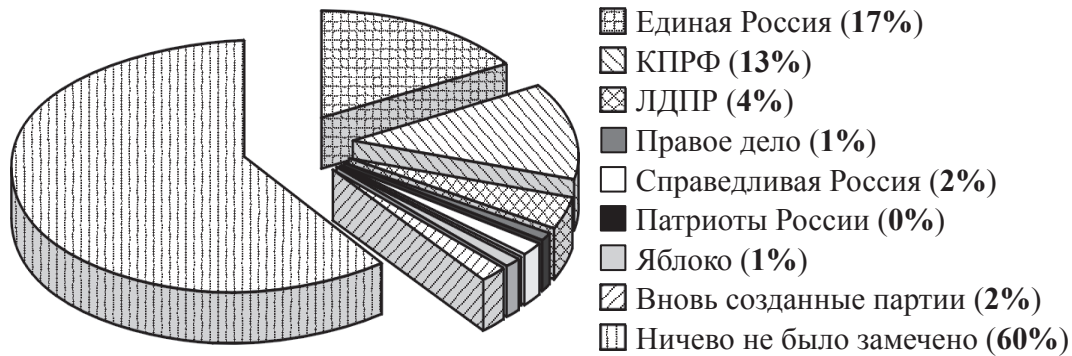

Как было выяснено нашим опросом, 40\% респондентов утверждают, что в течение последних трех месяцев (на момент исследования) заметили в городе деятельность политических партий. При этом наиболее активно себя проявили Единая Россия (17\%) и КПРФ (13\%). Однако больше половины (60\%) респондентов утверждают, что деятельность политических партий замечена не была (таблица 6). Что является плохим показателем для партийного менеджмента. Можно предположить, что связано это с тем, что большинство политических партий активизируют свою деятельность только в период проведения выборов, в то время как между избирательными кампаниями мы можем наблюдать некоторое «затишье» как среди топовых политических партий, так и среди наименее популярных и известных.

О том, что современные партии в мире стали далеко от идеалов былой политической репрезентации, нужд граждан, пишут многие политологи. Ещё Роберт Михельс предупреждал о тенденции пре-

\footnotetext{
1 На момент исследования.
} 
вращения руководства партий в олигархические группы, представляющие определённую опасность для демократии тем, что с их помощью политические элиты стали пользоваться партийной системой в целях удержания власти в государстве (Michels, 1968, с. 45), меньше заботясь о гражданах. Канадский политолог Крафорд Макферсон давал более резкую оценку роли современных партий. По его мнению, хотя партийная система и стала средством для смягчения социального размежевания, она теперь менее ответственна перед избирателями, предполагая лишь конкуренцию между несколькими элитами, оформленными в партии (Макферсон, с. 119).

Таблица 7

Уровень партийной принадлежности к какой-либо партии среди респондентов

\begin{tabular}{|l|c|}
\hline \multicolumn{1}{|c|}{ Являетесь ли вы членом какой-либо партии? } & В целом по выборке \\
\hline Да & $4 \%$ \\
\hline Нет & $96 \%$ \\
\hline
\end{tabular}

Вернемся к данным нашего опроса. По мнению $29 \%$ респондентов, Государственная Дума представляет интересы всего населения или большей его части ( $5 \%$ и $24 \%$ соответственно). $17 \%$ считают, что Госдума представляет интересы среднего класса. $50 \%$ респондентов считают, что Дума заботиться лишь об интересах власть имущих и олигархов ( $29 \%$ и $21 \%$ соответственно). При этом, учитывая низкий уровень оценки работы Госдумы среди 45\% молодежи, а также высокий процент мнения (27\%), что предвыборные обещания выбранная партия, скорее всего, не выполнит (при этом $19 \%$ респондентов ориентируются именно на них при голосовании; также можно учесть и респондентов (29\%), ориентирующихся на программу партии), можно сделать вывод о разочаровании в деятельности Государственной Думы России.

Таблица 8

Уровень доверия респондентов к парламентским партиям

\begin{tabular}{||c|c|}
\hline $\begin{array}{c}\text { Как Вы считаете, чьи интересы } \\
\text { представляют парламентские партии? }\end{array}$ & В целом по выборке \\
\hline \multicolumn{1}{|c|}{1} & 2 \\
\hline Всего населения & $5 \%$ \\
\hline Большей части населения & $24 \%$ \\
\hline
\end{tabular}




\begin{tabular}{|l|c|}
\hline \multicolumn{1}{|c|}{1} & 2 \\
\hline Интересы бедного населения & $1 \%$ \\
\hline Среднего класса & $17 \%$ \\
\hline Олигархов & $21 \%$ \\
\hline Интересы власть имущих & $29 \%$ \\
\hline Другое & $3 \%$ \\
\hline \hline
\end{tabular}

В октябре 2010 года Левада-центр провел всероссийский опрос, задав следующий вопрос гражданам: «Как Вы расценили бы людей, находящихся сейчас у власти?» (Как бы Bbl расценили). Большинство респондентов (43\%) ответили, что «это люди, озабоченные только своим материальным благополучием и карьерой». В декабре 2010 года Левада-центр поинтересовался у россиян: «Вкакой мере Вы согласны с утверждением: "Большинство политиков занимается политической деятельностью только ради личной выгоды"?» (В какой мере). Абсолютное большинство (65\%) согласились с утверждением, 22\% - согласились отчасти. Опрос на тему «Депутат Госдумы: образ идеальный и реальный» проведенный ВЦИОМ (Депутат Госдумы), пролил свет на представления россиян о типичном депутате Государственной Думы, которые оказались довольно противоречивы: с одной стороны, образованный (57\%), хороший оратор (56\%), профессионал (42\%), обаятельный (38\%). С другой - преследующий собственные интересы (60\%), оторванный от народа (57\%), нечестный (53\%), беспринципный (45\%), безответственный (42\%). Результаты выше названных опросов, в общей сложности сходятся: восприятие россиянами депутатов Госдумы носит яркий негативный характер. Что схоже с данными нашего исследования в вопросе о том, чьи интересы представляет Государственная Дума ${ }^{2}$.

Таблица 9

Пол респондентов

\begin{tabular}{|l|c|}
\hline & В целом по выборке \\
\hline Мужской & $48 \%$ \\
\hline Женский & $52 \%$ \\
\hline
\end{tabular}

2 Более подробные данные об опрошенных респондентах см. в таблицах 7 , $8,9,10,13$ и 14. 
Таблица 10

Возраст респондентов

\begin{tabular}{||l|c|}
\hline & В целом по выборке \\
\hline $18-25$ лет & $36 \%$ \\
\hline $26-34$ лет & $64 \%$ \\
\hline
\end{tabular}

Таблица 11

Образование респондентов

\begin{tabular}{|l|c||}
\hline & В целом по выборке \\
\hline Высшее & $46 \%$ \\
\hline Незаконченное высшее & $32 \%$ \\
\hline Среднее специальное & $18 \%$ \\
\hline Среднее & $4 \%$ \\
\hline
\end{tabular}

Таблица 12

Источник знакомства с политическими новостями

\begin{tabular}{|l|c||}
\hline \hline \multicolumn{1}{|c|}{ СМИ } & В целом по выборке \\
\hline ТВ & $23 \%$ \\
\hline Интернет & $66 \%$ \\
\hline Другое & $0 \%$ \\
\hline Радио & $9 \%$ \\
\hline Газеты & $2 \%$ \\
\hline Основной источник & $0 \%$ \\
\hline
\end{tabular}

Абсолютное большинство молодежи Москвы (таблица 12) указали как основной источник получения информации Интернет (66\%). Второе место заняло телевидение - 23\%. Это может быть связанно как с тех, что молодежь является наиболее передовой и открытой новому частью населения, так и с широкой доступностью Интернета в Москве.

Похожий опрос был проведен Всероссийским центром изучения общественного мнения (ВЦИОМ), который представил данные о том, из каких источников жители России предпочитают узнавать новости и насколько популярны сегодня интернет-издания (Онлайн и офлайн). По результатам опроса, среди молодого поколения от 18 до 34 лет абсолютное большинство набрали телевидение и Интернет: $34 \%$ и $50 \%$ среди людей от 18 до 24 , и $50 \%$ и $37 \%$ среди респондентов от 25 до 34 лет соответственно. Таким образом, в общей сложности, лидирует среди молодежи России Интернет. Данные ре- 
зультаты вполне согласуются с итогами нашего исследования. Правда, стоит отметить, что среди московской молодежи процент тех, для кого основным источником получения информации служит Интернет, является значительно выше, чем среди тех, для кого основной источник - телевидение.

Получается, что преобладающее влияние на политическое сознание молодежи, оказывает Интернет. Вследствие чего большее значение приобретает доступность к нему, и соответственно - место жительства. В городах с населением более ста тысяч жителей практически у всех пользователей (94\%) есть выход в Интернет из дома, причем у большинства из них - широкополосный (Развитие интернета). В то время как в селах показатели значительно ниже (Развитие интернета), если не сказать хуже. А, значит, и доступ к политической информации из разных источников намного меньше.

Таблица 13

\section{Род занятий}

\begin{tabular}{|l|c||}
\hline \multicolumn{1}{|c|}{ Род занятий } & В целом по выборке \\
\hline Работник науки & $6 \%$ \\
\hline Домохозяйка & $6 \%$ \\
\hline Военнослужащий & $1 \%$ \\
\hline Работник культуры & $10 \%$ \\
\hline Безработный & $1 \%$ \\
\hline Работник здравоохранения & $5 \%$ \\
\hline Работник образования & $4 \%$ \\
\hline Учащийся, студент & $5 \%$ \\
\hline Работник правоохранительных органов & $1 \%$ \\
\hline Индивидуальный предприниматель & $9 \%$ \\
\hline Работаю в негосударственном секторе & $43 \%$ \\
\hline Органы местного самоуправления & $0 \%$ \\
\hline Другое & $9 \%$ \\
\hline
\end{tabular}

Таблица 14

Материальное положение

\begin{tabular}{|l|c|}
\hline \hline & В целом по выборке \\
\hline Испытываем острую нужду & $1 \%$ \\
\hline Удовлетворительное & $20 \%$ \\
\hline Едва сводим концы с концами & $52 \%$ \\
\hline Не испытываем материальных трудностей & $20 \%$ \\
\hline Ни в чем себе не отказываем & $7 \%$ \\
\hline
\end{tabular}


Теперь перейдем к информационно-аналитическим связям, с использованием двойных, тройных распределений. Результаты представлены в таблицах 15-23.

Таблица 15

Уровень интереса к политике, в зависимости от пола и возраста

\begin{tabular}{|c|c|c|c|c|}
\hline \multirow{4}{*}{$\begin{array}{c}\text { Интересуетесь ли Вы } \\
\text { политикой? }\end{array}$} & \multicolumn{4}{|c|}{ Пол } \\
\hline & \multicolumn{2}{|c|}{ мужской } & \multicolumn{2}{|c|}{ женский } \\
\hline & \multicolumn{4}{|c|}{ возраст } \\
\hline & 18-25 лет & 26-34 лет & 18-25 лет & 26-34 лет \\
\hline Безусловно, интересуюсь & $33 \%$ & $51 \%$ & $15 \%$ & $34 \%$ \\
\hline Скорее интересуюсь & $35 \%$ & $22 \%$ & $33 \%$ & $30 \%$ \\
\hline Скорее не интересуюсь & $26 \%$ & $21 \%$ & $32 \%$ & $20 \%$ \\
\hline Совершенно не интересуюсь & $3 \%$ & $6 \%$ & $5 \%$ & $13 \%$ \\
\hline Затрудняюсь ответить & $3 \%$ & $0 \%$ & $15 \%$ & $3 \%$ \\
\hline
\end{tabular}

Наше исследование свидетельствует, что мужчины интересуются политикой больше (68\% среди мужчин от 18 до 25 и 73\% среди мужчин от 26 до 34 лет), чем женщины (48\% от 18 до 25 лет и 64\% среди женщин от 26 до 34). Кстати, процент мужчин, затруднившихся ответить на данный вопрос, значительно меньше, чем среди женщины: всего 3\% среди мужчин от 18 до 25 лет и 0\% среди 26-34 лет против $15 \%$ среди женщин от 18 до 25 лет и $3 \%$ женщин от 26 до 34 лет (таблица 15). Следовательно, больше всех политикой интересуются мужчины от 26 до 34 лет, при этом 51\% из них выражают безусловный интерес. Также и среди только женщин политикой больше интересуются представительницы более старшего возраста. Из чего можно сделать вывод, что с возрастом интерес к политике увеличивается.

Таблица 16

Уровень партийной принадлежности к какой-либо партии среди респондентов, в зависимости от пола и возраста

\begin{tabular}{|c|c|c|c|c|}
\hline \multirow{4}{*}{$\begin{array}{c}\text { Являетесь ли вы членом } \\
\text { какой-либо партии? }\end{array}$} & \multicolumn{4}{|c|}{ Пол } \\
\hline & \multicolumn{2}{|c|}{ мужской } & \multicolumn{2}{|c|}{ женский } \\
\hline & \multicolumn{4}{|c|}{ возраст } \\
\hline & 18-25 лет & 26-34 лет & 18-25 лет & 18-25 лет \\
\hline Да & $8 \%$ & $4 \%$ & $3 \%$ & $2 \%$ \\
\hline \begin{tabular}{|l} 
Нет \\
\end{tabular} & $92 \%$ & $96 \%$ & $97 \%$ & $98 \%$ \\
\hline
\end{tabular}


$4 \%$ респондентов на вопрос „Являетесь ли вы членом какой-либо партии?” ответили утвердительно. Причем наиболее активно в партии вступают мужчины, в частности, в возрасте от 18 до 25 лет. Что коррелирует с повышенным интересом к политике у данной группы (см. табл. 16).

Таблица 17

\section{Мотивация выбора при голосовании за партию,} в зависимости от пола и возраста

\begin{tabular}{|c|c|c|c|c|}
\hline \multirow{4}{*}{$\begin{array}{l}\text { Что, на Ваш взгляд, является наиболее } \\
\text { важным при голосовании за партию? }\end{array}$} & \multicolumn{4}{|c|}{ Пол } \\
\hline & \multicolumn{2}{|c|}{ мужской } & \multicolumn{2}{|c|}{ женский } \\
\hline & \multicolumn{4}{|c|}{ возраст } \\
\hline & $\begin{array}{c}18-25 \\
\text { лет }\end{array}$ & $\begin{array}{c}26-34 \\
\text { лет }\end{array}$ & $\begin{array}{c}18-25 \\
\text { лет }\end{array}$ & $\begin{array}{c}\text { 26-34 } \\
\text { лет }\end{array}$ \\
\hline Программа партии & $33 \%$ & $20 \%$ & $29 \%$ & $31 \%$ \\
\hline Лидер партии & $24 \%$ & $29 \%$ & $11 \%$ & $20 \%$ \\
\hline $\begin{array}{l}\text { Принятие решений, поддерживаемые боль- } \\
\text { шинством общества }\end{array}$ & $0 \%$ & $4 \%$ & $14 \%$ & $2 \%$ \\
\hline Поддержка партии президентом & $20 \%$ & $33 \%$ & $14 \%$ & $12 \%$ \\
\hline Степень оппозиционности к партии власти & $8 \%$ & $10 \%$ & $3 \%$ & $5 \%$ \\
\hline Выполнение предвыборных обязательств & $15 \%$ & $4 \%$ & $29 \%$ & $30 \%$ \\
\hline
\end{tabular}

Среди мужчин в возрасте от 18 до 25 лет, как показал наш опрос, результаты соответствуют показателям среди всей московской молодежи (таблица 17). Среди мужчин от 26 до 34 лет наиболее важным мотивом голосования (33\%) является поддержка партии президентом, второе место заняла ориентация на лидера партии (29\%). Меньше всех на программу ориентируются мужчины старшей возрастной группы (20\%), хотя этот мотив по популярности занимает среди них 3-е место. При этом больше всех обращают внимание на программу политической партии мужчины от 18 до 25 лет (33\%). Среди женщин лидирующими мотивами оказались - программа партии (18-25 лет -29\%, 26-34 года - 31\%) и выполнение предвыборных обязательств (18-25 лет - 29\%, 26-34 года - 30\%). Также примерно равное количество процентов среди женщин набрала поддержка партии президентом (18-25 лет - 14\%, 26-34 года - 12\%). Между тем, женщины в возрасте от 18 до 25 лет больше ориентируются на принятые ре- 
шения, поддерживаемые большинством общества, нежели на лидеров партий, а среди женщин старшей возрастной группы - наоборот: $20 \%$ ориентируются на лидеров, а на решения обращают гораздо меньше внимания - всего $2 \%$.

Наше исследование выявило, что мужчины в большей степени, чем женщины (среди московской молодежи), ориентируются на конкретного человека - лидера. Также мужчины немного больше (8\% и 10\%), чем женщины, обращают внимание на оппозиционность партии ( $3 \%$ и $5 \%)$. Что может говорить о большей склонности к состязательности и борьбе. Для женщин же наиболее важным мотивами являются программа партии и выполнение ею предвыборных обязательств. Помимо этого, у женщин младшей возрастной группы остальные мотивы набрали примерно одинаковое количество процентов, кроме оппозиционности партии к партии власти (всего 3\%). Таким образом, эту возрастную группу можно охарактеризовать как мягкую, желающую в большей степени достичь единства, готовую идти на компромисс. Стоит также заметить, что 14\% женщин от 18 до 25 лет ориентируются на решения, поддерживаемые большинством, что значительно выше по сравнению с результатами других групп (что интересно, на это ориентируется $0 \%$ мужчин той же возрастной группы). Можно предположить, что женщины от 18 до 25 лет имеют слабо выраженные политические предпочтения и в большей степени ориентируются на понятия справедливости и общности. Женщины же более старшего поколения уже больше начинают обращать внимание на лидеров партий. Хотя в целом превалирующими мотивами для женщин остаются программа и выполнение предвыборных обязательств.

Мужчины от 18 до 25 лет, хотя и интересуются политикой меньше, чем более старшее их поколение, все же больше всего обращают внимание на программы и чаще становятся членами партий. Возможно, ввиду того, что только находятся в поиске своей идеологической идентичности, и только осваивают новую для себя роль политически активного гражданина. Мужчины же от 26 до 34 лет имеют ярко выраженный интерес к политике, при этом при голосовании ориентируются в большей степени на президента и лидеров партий. Отсюда можно сделать вывод, что опору действующая власть может найти, скорее, среди старшего поколения мужчин. 
Уровень интереса к политике, в зависимости от профессиональной деятельности (группировка респондентов на бюджетную сферу и частный сектор)

\begin{tabular}{||c|c|c|}
\hline $\begin{array}{c}\text { Интересуетесь ли Вы } \\
\text { политикой? }\end{array}$ & $\begin{array}{c}\text { Работники частного } \\
\text { сектора }\end{array}$ & $\begin{array}{c}\text { Работники } \\
\text { бюджетной сферы }\end{array}$ \\
\hline Безусловно, интересуюсь & $40 \%$ & $27 \%$ \\
\hline Скорее интересуюсь & $30 \%$ & $29 \%$ \\
\hline Скорее не интересуюсь & $21 \%$ & $27 \%$ \\
\hline Совершенно не интересуюсь & $6 \%$ & $11 \%$ \\
\hline Затрудняюсь ответить & $3 \%$ & $6 \%$ \\
\hline
\end{tabular}

Таблица 19

Результаты гипотетических выборов в Госдуму по партийным спискам в зависимости от профессиональной деятельности (распределение респондентов на бюджетную сферу и частный сектор)

\begin{tabular}{|l|c|c|}
\hline $\begin{array}{c}\text { Какой партии Вы бы отдали } \\
\text { предпочтение на гипотетических } \\
\text { выборах в Госдуму? }\end{array}$ & $\begin{array}{c}\text { Работники } \\
\text { частного сектора }\end{array}$ & $\begin{array}{c}\text { Работники } \\
\text { бюджетной сферы }\end{array}$ \\
\hline Единая Россия & $46 \%$ & $29 \%$ \\
\hline ЛДПР & $7 \%$ & $8 \%$ \\
\hline КПРФ & $5 \%$ & $14 \%$ \\
\hline Справедливая Россия & $3 \%$ & $9 \%$ \\
\hline Непарламентская партия & $4 \%$ & $6 \%$ \\
\hline Не пойду на выборы & $16 \%$ & $15 \%$ \\
\hline Затрудняюсь ответить & $19 \%$ & $19 \%$ \\
\hline
\end{tabular}

О выполнении предвыборных обязательств представителями власти в зависимости от профессиональной деятельности (распределение респондентов на бюджетную сферу и частный сектор)

\begin{tabular}{|l|c|c|}
\hline $\begin{array}{c}\text { Оцените насколько вероятно, по вашему } \\
\text { мнению, что поддержанная вами партия, } \\
\text { выполнит предвыборные обязательства }\end{array}$ & $\begin{array}{c}\text { Работники } \\
\text { частного } \\
\text { сектора }\end{array}$ & $\begin{array}{c}\text { Работники } \\
\text { бюджетной } \\
\text { сферы }\end{array}$ \\
\hline Безусловно, выполнит & $4 \%$ & $14 \%$ \\
\hline Скорее выполнит & $13 \%$ & $36 \%$ \\
\hline Выполнит только часть & $32 \%$ & $15 \%$ \\
\hline Скорее не выполнит & $24 \%$ & $12 \%$ \\
\hline Точно не выполнит & $4 \%$ & $9 \%$ \\
\hline Затруднились ответить & $23 \%$ & $14 \%$ \\
\hline
\end{tabular}


Мотивация выбора при голосовании за партию в зависимости от профессиональной деятельности (распределение респондентов на бюджетную сферу и частный сектор)

\begin{tabular}{||l|c|c|}
\hline \multicolumn{1}{|c|}{$\begin{array}{c}\text { Что, на Ваш взгляд, является наиболее } \\
\text { важым при голосовании за партию? }\end{array}$} & $\begin{array}{c}\text { Работники } \\
\text { частного } \\
\text { сектора }\end{array}$ & $\begin{array}{c}\text { Работники } \\
\text { бюджетной } \\
\text { сферы }\end{array}$ \\
\hline Программа партии & $13 \%$ & $46 \%$ \\
\hline Лидер партии & $24 \%$ & $18 \%$ \\
\hline $\begin{array}{l}\text { Принятие решений, поддерживаемые боль- } \\
\text { шинством общества }\end{array}$ & $6 \%$ & $3 \%$ \\
\hline Поддержка партии президентом & $29 \%$ & $9 \%$ \\
\hline Степень оппозиционности к партии власти & $9 \%$ & $3 \%$ \\
\hline Выполнение предвыборных обязательств & $19 \%$ & $21 \%$ \\
\hline
\end{tabular}

Таблица 22

Оценка респондентами уровня работы действующей Госдумы, в зависимости от профессиональной деятельности (распределение респондентов на бюджетную сферу и частный сектор)

\begin{tabular}{||l|c|c|}
\hline $\begin{array}{c}\text { Оценка респондентами уровня } \\
\text { работы действующей Госдумы }\end{array}$ & $\begin{array}{c}\text { Работники } \\
\text { частного сектора }\end{array}$ & $\begin{array}{c}\text { Работники } \\
\text { бюджетной сферы }\end{array}$ \\
\hline Отлично & $5 \%$ & $9 \%$ \\
\hline Хорошо & $15 \%$ & $21 \%$ \\
\hline Средне & $18 \%$ & $30 \%$ \\
\hline Удовлетворительно & $8 \%$ & $4 \%$ \\
\hline Неудовлетворительно & $51 \%$ & $27 \%$ \\
\hline Затруднились ответить & $3 \%$ & $9 \%$ \\
\hline
\end{tabular}

Таблица 23

Уровень доверия респондентов к парламентским партиям, в зависимости от профессиональной деятельности (распределение респондентов на бюджетную сферу и частный сектор)

\begin{tabular}{|l|c|c|}
\hline $\begin{array}{c}\text { Как Вы считаете, чьи интересы } \\
\text { представляют парламентские партии? }\end{array}$ & $\begin{array}{c}\text { Работники } \\
\text { частного } \\
\text { сектора }\end{array}$ & $\begin{array}{c}\text { Работники } \\
\text { бюджетной сферы }\end{array}$ \\
\hline Всего населения & $2 \%$ & $8 \%$ \\
\hline Большей части населения & $12 \%$ & $38 \%$ \\
\hline Интересы бедного населения & $1 \%$ & $1 \%$ \\
\hline Среднего класса & $19 \%$ & $15 \%$ \\
\hline Олигархов & $24 \%$ & $19 \%$ \\
\hline Интересы власть имущих & $38 \%$ & $16 \%$ \\
\hline Другое & $3 \%$ & $3 \%$ \\
\hline
\end{tabular}


Теперь обратимся к результатам нашего проса, нацеленным на анализ отношения молодежи Москвы к парламенту в зависимости от принадлежности к бюджетному и частному сектору. Следует подчеркнуть, что эти целевые группы населения во многих странах так или иначе стараются воздействовать на свои национальные парламенты. Анализ этих двух групп позволит создать дееспособный механизм агрегирования интересов с целью выработки политических решений, адекватных для основных страт населения, что, в свою очередь создаст конкурентные условия хозяйственной деятельности и минимизирует получение «политической ренты» представителями власти и бизнеса (Расторгуев, 2014, с. 5).

Социологическое исследование, проведенное нами, отчетливо показало, что среди молодежи Москвы работники частного сектора в той или иной степени гораздо больше интересуются политикой, чем работники бюджетной сферы (70\% против 56\%). Однако стоит отметить, что в обеих группах заинтересованы политикой больше половины респондентов.

В случае проведения выборов в ближайшее время (на момент исследования), партию власти (без учета явки) больше бы поддержали работники частного сектора экономики - 46\%, в то время как бюджетники отдали бы ей в 1,5 раза меньше голосов - 29\%. Большей популярностью (по сравнению с людьми из частного сегмента) среди работников бюджетной сферы пользуются такие партии как КПРФ (14\% против 5\%) и Справедливая Россия (9\% против 3\%). Эти две партии позиционируют себя как левые и противопоставляют свою идеологию партии власти (Единой России). Поддержка их группами московской молодежи из бюджетной сферы говорит о некотором уменьшении их доверия к нынешнему курсу власти. Тем не менее, каждый второй работник бюджетной сферы уверен, что выбранная им партия выполнит предвыборные обязательства, 15\% считает, что партия выполнит только часть. Но при выборе партии руководствуются в первую очередь ее программой (46\%), далее ориентируется на предвыборные обязательства (21\%). Тогда как среди московских работников молодежи частного сектора только $17 \%$ придерживаются мнения, что партия выполнит обязательства, большая же часть - 32\%, уверена, что партия выполнит только часть предвыборных обязательств, и $28 \%$ разделяют мнение, что партия обязательства не выполнит. Высока, также, среди частников доля тех, у кого ответ на данный вопрос вызвал затруднения (23\%). Возможно, это связано 
с тем, что выполнение предвыборных обязательств важно только для $19 \%$ из них (еще ниже показатель у программы партии - 13\%), по сравнению, например, с такими лидирующими мотивами как поддержка партии президентом (29\%) и лидер партии (24\%).

Среди работников бюджетной сферы на лидера ориентируются в меньшей степени - $18 \%$, а поддержка партии президентом важна только для 9\% (в то время как на выборах бюджетники отдали бы Единой России 29\% голосов).

Интересно распределились мнения о работе Госдумы. Больше половины частников оценивает ее работу как неудовлетворительно - 51\%, при этом 8\% характеризуют ее как «удовлетворительная». В больше или меньшей степени одобряют деятельность Госдумы $38 \%$ работников частного сектора, что значительно меньше, чем среди бюджетников (60\%). Не удовлетворены работой Госдумы $27 \%$ работников бюджетной сферы, 4\% оценивают ее как «удовлетворительно». Иными словами, частный сектор, поддерживающий Единую Россию и ориентирующиеся при голосовании на президента, в большинстве своем недоволен работой Госдумы. В то время как бюджетный сектор, меньше поддерживающий партию власти и ориентирующийся в первую очередь на программу, работой парламента доволен. Вполне вероятно, это связано с тем, что 38\% работников бюджетной сферы считают, что, несмотря на то, что состав действующей Государственной Думы наполовину состоит из депутатов от Единой России (которая пользуется среди них меньшей популярностью, нежели среди частников), парламент представляет интересы большей части населения, а 15\% считают, что Дума выражает интересы среднего класса.

Среди представителей бюджетной молодежи (35\%) велика доля тех, кто считает, что Дума защищает интересы только олигархов и власть имущих (19\% и 16\% соответственно). Этой же точки зрения придерживается $62 \%$ работников частной сферы экономики. $19 \%$ частников считают, что Госдума защищает интересы среднего класса (что практически совпадает с мнением бюджетников), и 12\% находят, что Дума заботиться о большей части населения (что на $26 \%$ меньше по сравнению с бюджетниками).

Таким образом, можно сделать вывод, что частный сектор московской молодежи, в большей степени интересующийся политикой в отличие от работников бюджетной сферы, поддерживает политический курс президента и готов голосовать за поддерживаемую 
им партию - Единую Россию. Частный сектор считает, что предвыборные обязательства выбранная партия не выполнит, критически оценивая работу Государственной Думы, которая, по его мнению, по большой части представляет интересы олигархов и власть имущих.

Представители же бюджетной сферы, в меньшей степени, чем частный сектор, интересуются политикой. И при выборе партии они больше ориентируются на ее программу и предвыборные обещания, возможно потому, что уверены в их реализации. В меньшей же степени бюджетники выражают желание сохранить состав ныне действующей Госдумы неизменным: часть лояльного электората (в том числе существенная часть разницы проголосовавших за Единую Россию среди частников и бюджетников) предпочитает левые партии - КПРФ и Справедливую Россию. При этом, в отличие от работников частного сектора, бюджетный сектор, несмотря на несоответствуюший их политическим предпочтения состав Государственной Думы, одобряет в большей или меньшей степени ее работу и считает, что она представляет интересы простого населения.

\section{Распределение Гаусса}

Нормальное (гауссовское) распределение занимает центральное место в теории и практике вероятностно-статистических исследований. Нормальным распределением хорошо моделируются погрешности измерений. Ниже представлен график плотности нормального распределения. Этот график называют нормальной кривой или кривой Гаусса (график 1).

Как наглядно показано, распределения в нашей работе в двух исследуемых группах, «стремятся к нормальному». В 1-й группе распределение незначительно смещено вправо, некоторая часть респондентов выпадает из общего тренда (график 2). Во 2-й группе несколько выше доля крайних оценок работе парламента, что также незначительно (график 3). На этом основании можно сделать вывод, что распределение, в обоих случаях, стремится к нормальному.

Таким образом, проведенное нами сравнительное социологическое исследование обладает важным показателем научной объективности. 


\section{График 1. Нормальное распределение Гаусса}

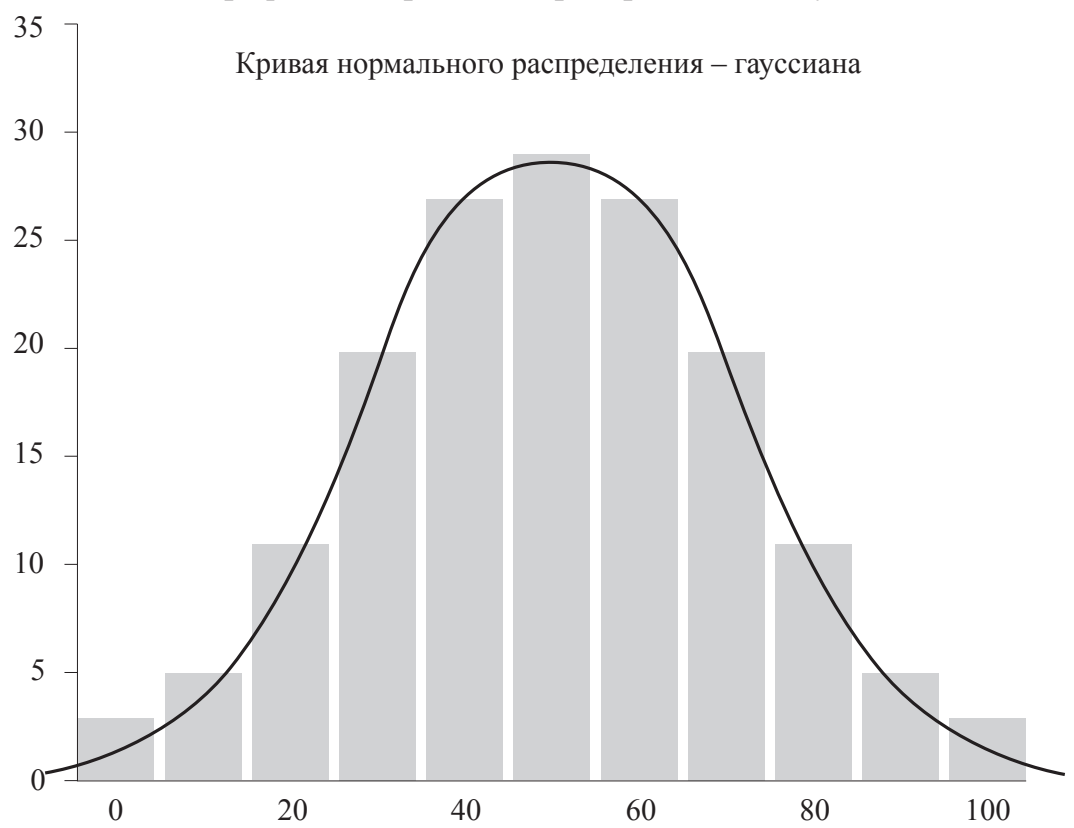

График 2. 1-я группа респондентов (представители частной сферы)

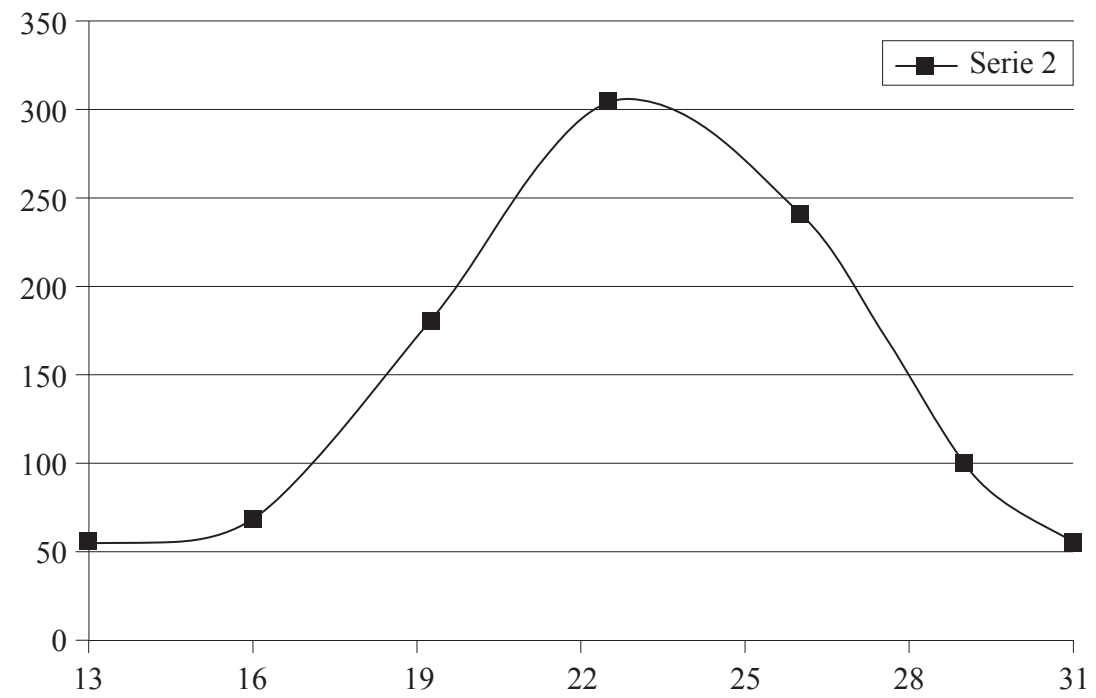


График 3. 2-я группа респондентов (представители бюджетной сферы)

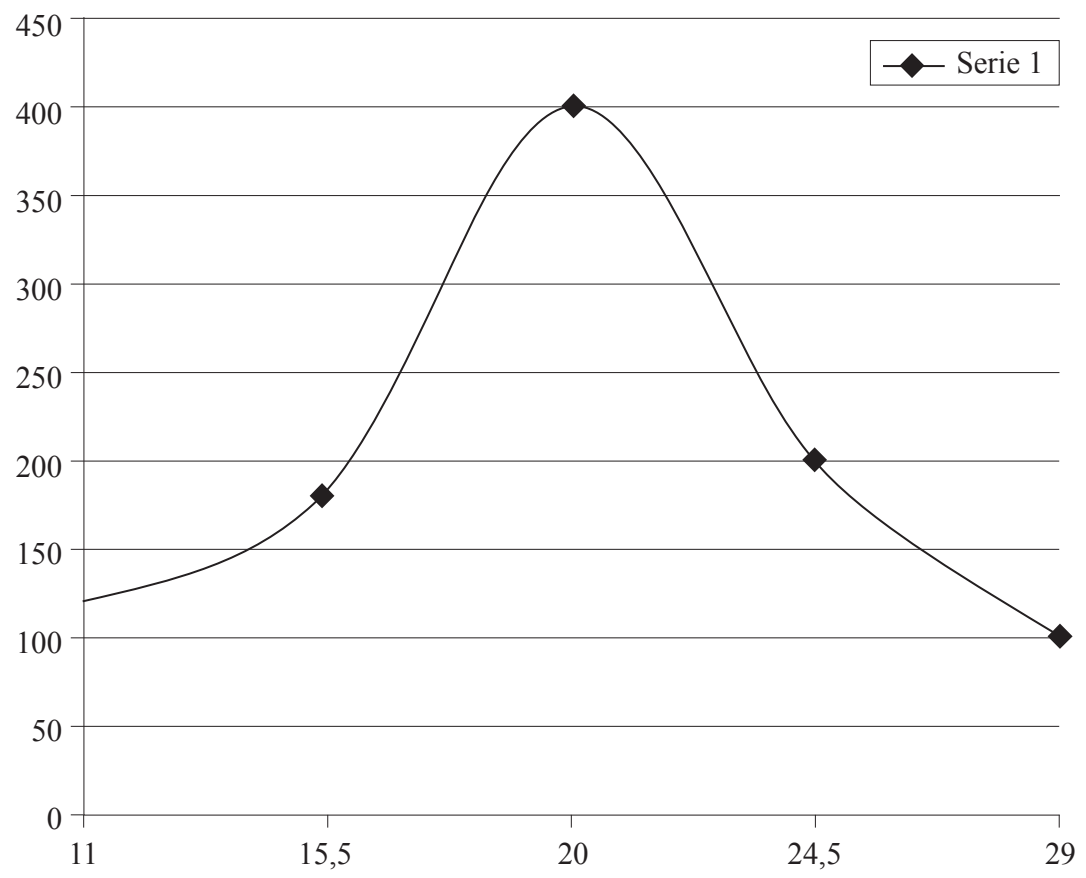

Делая выводы по проведенному исследованию, важно отметить, что больше половины опрошенной молодежи Москвы активно интересуется политикой. При этом высока доля тех, кто желает участвовать в выборах, но не может определиться с тем, кому отдать свой голос (причем, среди московской молодежи этот процент выше, чем в целом по стране). Что не удивительно - больше половины респондентов в последние три месяца (на момент исследования) не заметили активности со стороны политических партий. (Выше этот феномен объяснялся неэффективным применением технологий партийного менеджмента и рекрутинга).

Можно говорить либо о слабой политической идентичности молодежи, либо об отсутствии партии, отражающей ее интересы. Если же дело именно в последнем, то люди, желающие принимать участие в политике, интересующиеся ей, фактически не могут адекватно выразить свои политические предпочтения, чем представляют собой значительный электорат для оппозиции. Хотя, учитывая, что 
всего 7\% молодежи при голосовании ориентируются на степень оппозиционности к господствующей партии, а также низкий процент голосования за непарламентские партии, можно говорить о лояльности к действующей власти. Из этого следует, что дело все-таки в низкой политической идентичности. То есть те ценности, нормы и убеждения, содержащиеся в политической идеологии, которые должны были бы служить ориентирами к действию, не усваиваются молодежью. При лидирующем показателе спроса на программы партий, проблема может заключаться либо в том, что партия не предпринимает каких-либо действий для распространения и разъяснения своей идеологии, либо в том, что идеология партии не находит отклика у населения, либо она вовсе отсутствует или не претворяется в жизнь. Во всяком случае, партии, представляющие собой такую хрупкую политическую идентичность в идеологическом и партийном проявлении, не могут выполнять функцию выражения интересов граждан.

Отечественный партийный менеджмент показывает слабое применение технологий рекрутинга молодежи в состав политических организаций. Партии вне предвыборного временного лага очень мало занимаются необходимыми проектами для населения (политическое просвещение молодежи, патриотическое воспитание подрастающего поколения, пропаганда демократических ценностей среди населения, экология, парламентские расследования, мониторинг применения законодательства и т.п.).

Результаты исследования показывают, что российский политический менеджмент не отражает реалий граждан и их политических предпочтений (Федорченко, 2013). Институциональное влияние политических партий ограничивается: партия активизирует свою деятельность только в период проведения выборов, в то время как между избирательными кампаниями мы наблюдаем некоторое «затишье», причем не только среди непарламентских партий (а их низкая популярность подтверждает выше сказанное: ведь большинство из них зарегистрированы до проведения очередных выборов - в 2012 году), но и среди топовых политических партий (в том числе и парламентских). Хотя стоит отметить, что $40 \%$ все же заметили деятельность партий за последние три месяца, причем $17 \%$ респондентов заметили деятельность Единой России и 13\% - КПРФ. Эти же партии лидируют на гипотетических выборах: Единая Россия - 57\%, КПРФ - 14\% (с учетом явки). Однако, по сравнению с результатами 
в целом среди россиян, популярность Единой России среди молодежи Москвы значительно ниже, и не в последнюю очередь, за счет тех, кто не смог определиться с ответом, а также тех, кто не пойдет на выборы (а доля их среди молодежи высока и гораздо больше, чем среди россиян). Это означает, что большая доля абсентеистов среди молодежи должна стать тревожным сигналом для политической системы и элиты. Если среди самой российской молодежи число абсентеистов будет расти, то в случае каких-либо социальных потрясений, катаклизмов или кризисов, эта группа населения либо перейдет на сторону радикальной оппозиции, либо окажется равнодушной к нынешнему механизму политической системы.

Дополнительной причиной обозначенных процессов может быть утрата среди молодежи Москвы веры в демократические институты. Например, половина молодежи низко оценивает работу Государственной Думы, считает, что парламент представляет интересы олигархов и власть имущих. Также распространение получило мнение, что предвыборные обещания выбранная партия, скорее всего, не выполнит. Иными словами, у около половины молодежи нет политической опоры, нет альтернативы выбора, нет политического доверия, а значит, нет возможности и смысла участвовать в политической жизни.

Другая же половина молодежи, наоборот, одобряет деятельность Госдумы, считает, что она представляет интересы всего населения или большей его части. Многие считают, что парламент выражает интересы среднего класса. Также значительная часть молодежи ориентируется на президента при голосовании за партию. А также, в случае проведения выборов в ближайшее время (на период исследования), больше всего голосов наберет Единая Россия.

Сущуественных различий в отношениях молодежи бюджетной сферы и молодежи из частного сектора экономики не выявлено (таким образом, прежняя гипотеза не подтвердилась). Молодежь одинаково критически оценивает выстроенный в России институт парламентаризма. Правда, высока доля тех, кто объясняет свой выбор партии из-за роли президента (20\%), что говорит о понимании сильной зависимости парламента от института президентуры.

Так или иначе, при всей низкой оценке работы парламента (39\% ответили неудовлетворительно на вопрос об оценки работы Государственной Думы, 6\% удовлетворительно), высока доля поддержки партии власти (37\% без учета явки, 55\% из тех, кто пойдет на вы- 
боры). На вопрос, чьи интересы представляют парламентские партии, 50\% респондентов указали олигархов или власть имущих $(21 \%$ и $29 \%$ соответственно).

В настоящее время наблюдается определенная дуальность позиций молодежи по поводу парламента. Во-первых, половина представителей молодежи разочарована в деятельности нижней палаты парламента России. Присутствует даже некоторое уныние насчет развития демократического института парламентаризма. Во-вторых, часть молодежи готова ходить на выборы, поддерживать действующий курс развития политической системы (голосование за непарламентские партии находится на низком уровне (5\%), что говорит о нежелании менять состав Государственной Думы).

Следовательно, пока технологии отечественного партийного менеджмента, несмотря на некоторую либерализацию партийного строительства в 2012 году, больше способствуют социальному размежеванию молодежи, чем её консолидации вокруг конкретных и понятных политических идей.

\section{Библиография}

Абрамов А. В., Федорченко С. Н. (2014), Исследовательский проект ,,Идеальная партия России”, „Вестник Московского государственного областного университета", Серия: История и политические науки, № 1.

В какой мере Вы согласны с утверждением: «Большинство политиков занимается только ради личной выгодыl»? [Электронный ресурс], http:// www.levada.ru/archive/gosudarstvo-i-obshchestvo/politicheskoe-uchastie/v-kakoi-mere-vy-soglasny-s-utverzhdeniem-bo, 5.03.2015.

Депутат Госдумы: образ идеальный и реальный (2013), „Пресс-выпуск ВЦИОМ”, № 2289.

Дмитриев А. Е., Журавлёва Л. В., Федорченко С. Н. (2011), Проблема классификации политических консультантов в современной России, „Известия Московского государственного технического университета МАМИ”, № 2, с. 155-161.

Как бы Вы расченили людей, находящихся сейчас у власти? [Электронный pecypc], http://www.levada.ru/archive/gosudarstvo-i-obshchestvo/grazhdane-i-vlast/kak-vy-rastsenili-lyudei-nakhodyashchikhsya-seic, 5.03.2015.

Макферсон К. (2011), Жизнь и времена либеральной демократии, ВШЭ, М., c. $104,119$.

Мотивации голосования за ту или иную партию [Электронный ресурс], http://www.levada.ru/25-11-2011/vybory-v-gosdumu, 5.03.2015. 
O Госдуме и ее работе [Электронный ресурс], http://fom.ru/Politika/11264, 5.03.2015.

Одобрение деятельности государственных институтов [Электронный ресурс], http://wciom.ru/ratings-state-institutions/, 5.03.2015.

Онлайн и офлайн: откуда получают информащию россияне (2013), „Прессвыпуск ВЦИОМ”, № 2370.

Развитие интернета в регионах России. Яндекс [Электронный ресурс], http://advertising.yandex.ru/i/download/Regional_internet-07.pdf, 5.03.2015.

Расторгуев С. В. (2014), Партнерство и соперничество во власти и в бизнесе в современной России. М.: Политическая энциклопедия, с. 5.

Федеральный закон от 2 апреля 2012 года № 28-Ф3 «О внесении изменений в Федеральный закон „О политических партиях” (2012), „Российская газета”, 4.04.2012, № 73 .

Федорченко С. Н. (2013), Искусство политического менеджмента: монография, ИИУ МГОУ, М.

Штоль В. В., Федорченко С. Н. (2013), Технологии политического менеджмента в российском партстроительстве, „Обозреватель-Observer”, № 6.

Электоральный рейтинг политических партий [Электронный ресурс], http:// wciom.ru/ratings-parties/, 5.03.2015.

Bobbio N. (1984), Il futuro della democrazia, Einaudi, Turin.

Henneberg S. C., Scammell M., O’Shaughnessy N. J. (2009), Political Marketing Management and Theories of Democracy, „Marketing Theory”, № 9, № 2, c. $165-188$.

Michels R. (1968), Political Parties. A Sociological Study of the Oligarchical Tendencies of Modern Democracy, The Free Press, N.Y.-L., c. 45.

Schläger C., Christ J. (2014), Modern Political Party Management - What Can Be Learned from International Practices?, Shanghai, Friedrich-Ebert-Stiftung, Shanghai Coordination Office for International Cooperation.

\section{Echo of Party Management: trust of the youth from the city of Moscow to the State Duma of the Russian Federation}

\section{Summary}

The article is based on the results of sociological research of the youth from the city of Moscow. The analysis showed that there is some duality in Moscow youth's opinions in relation to the State Duma of the Russian Federation. The researchers concluded that in contrast to public sector employees, who support the political course of the current president and are ready to vote for the party „United Russia”, young people from the private sector are more interested in politics, although their criticism of parliamentarism. However, young people from the public sector are less interested 
in politics and endorses to a greater or lesser extent the work of the State Duma of Russia, believing that it represents the interests of ordinary people.

Key words: party management, the State Duma of the Russian Federation, the Russian parties, parliament, the youth of Moscow, democracy

\section{Echo Zarządzania Partią: zaufanie młodzieży miasta Moskwy do Dumy Państwowej Federacji Rosyjskiej}

\section{Streszczenie}

Artykuł napisano w oparciu o wyniki badań socjologicznych przeprowadzonych wśród młodzieży Moskwy. Analiza wykazała pewną dwoistość w stosunku moskiewskiej młodzieży do Dumy Państwowej Federacji Rosyjskiej. Badacze doszli do wniosku, że w przeciwieństwie do młodych pracowników sektora publicznego, którzy wspierają kurs polityczny obecnego prezydenta i gotowi są głosować na partię „Jedna Rosja" - młodzież z sektora prywatnego bardziej interesuje się polityką, choć krytycznie ocenia parlamentaryzm. Natomiast młodzi ludzie z sektora publicznego mniej interesują się polityką i w większym lub mniejszym stopniu popierają prace Dumy Państwowej Rosji, wierząc, że reprezentuje ona interesy zwykłych ludzi.

Słowa kluczowe: menedżment partyjny, Duma Państwowa Federacji Rosyjskiej, partie rosyjskie, parlament, młodzież Moskwy, demokracja 